ELŻBIETA BAGIŃSKA (Białystok)

\title{
DZIAŁALNOŚĆ RELIGIJNA RADZIWIŁŁÓW BIRŻAŃSKICH W DOBRACH PODLASKICH W XVII WIEKU*
}

\section{Wstęp}

O działalności Radziwiłłów birżańskich na polu religijnym mówiono i pisano już wielokrotnie, najczęściej traktując ich jako liderów dysydentów w Wielkim Księstwie Litewskim. Mało jest jednak monografii tyczących się ich działalności religijnej w poszczególnych kluczach majątkowych znajdujących się zarówno na terenie Korony jak i W.Ks.Lit. Zestawienie wyników tych badań pozwoliłoby potem na pełną charakterystykę prowadzonej przez nich polityki religijnej w stosunku do własnych poddanych i porównanie jej z deklaracjami wygłaszanymi choćby w izbie sejmowej.

Niniejszy szkic ma na celu omówienie działalności religijnej Radziwiłłów birżańskich w dobrach, które w źródłach XVI i XVII-wiecznych określane są jako podlaskie. W końcu XVI wieku weszli oni w posiadanie kilku kluczy majątkowych na Podlasiu: klucza zabłudowskiego w powiecie grodzieńskim, orlańskiego w ziemi bielskiej i dóbr starowiejsko-węgrowskich w ziemi drohickiej. Związek z Podlasiem skończył się w sposób naturalny w roku 1695 wraz ze śmiercią Ludwiki Karoliny, jedynej córki Bogusława Radziwiłła. U schyłku XVI wieku zastali Radziwiłłowie w dobrach podlaskich dość skomplikowaną sytuację wyznaniową, która z czasem skomplikowała się jeszcze bardziej. Obok katolików mieszkała tam bowiem ludność prawosławna, a prócz nich Żydzi i arianie (antytrynitarze), w XVII wieku pojawi-

* Artykuł ten jest rozszerzoną wersją referatu wygłoszonego na posiedzeniu Komisji Lituanistycznej w IH PAN w Warszawie 25 września 2002 roku. 
li się unici i luteranie, a razem z Radziwiłłami ewangelicy reformowani, nie było natomiast Tatarów ${ }^{1}$. Niektóre $z$ dóbr podlaskich Radziwiłłów pełniły w XVII wieku, niekiedy jednocześnie, rolę centrów różnych wyznań, niekoniecznie chrześcijańskich.

\section{Ewangelicy reformowani}

Podlasie (historyczne) należało w XVII wieku zarówno do Korony jak i do Litwy, a podział administracyjny w żadnym stopniu nie pokrywał się ze strukturą kościelną. Podlasie w sensie administracyjnym należało do prowincji małopolskiej, natomiast w przypadku struktur kościoła ewangelicko-reformowanego należało do prowincji litewskiej, stanowiąc jeden $\mathrm{z}$ jej sześciu dystryktów. Na trudność w ustaleniu pełnej liczby zborów w prowincji litewskiej, zwłaszcza w XVII wieku zwracał już uwagę Stanisław Tworek, a niedawno Wojciech Kriegseisen. Według obliczeń Tworka, w latach 1611-1640 prowincja litewska liczyła 140 zborów, w latach 1641-1655-110, a w 1696 roku tylko $51^{2}$. Z wykazu sporządzonego w 1716 roku wynika, że było ich już tylko $45^{3}$. Ilość zborów w dystrykcie podlaskim wahała się w tym czasie od 6 do $8^{4}$, przy czym nie wszystkie istniały w tym samym czasie. Zbory w Węgrowie, Orli, Zabłudowie (zbór katedralny - miejsce przebywania seniora podlaskiego), zbór w Sielcu, poza tym w Sokołowie i w Starej Wsi ${ }^{5}$ znajdowały się $\mathrm{w}$ majętnościach radziwiłłowskich. Poza tym Łukaszewicz przypuszcza, że w radziwiłłowskich Siemiatyczach, w końcu XVI wieku, również istniał zbór ${ }^{6}$. Kiedy do tego dodamy zbór w Nurcu, w ziemi brzeskiej,

1 P. Borawski, Tatarzy $w$ miastach $i$ jurydykach Radziwitłów, „PH” 1992, t. LXXXIII, z. 1, s. 65-81.

2 S. Tworek, Z zagadnień liczebności zborów kalwińskich na Litwie, „OiRwP” 1972, t. XVII, s. 211-212; W. Kriegseisen, Ewangelicy polscy i litewscy w epoce saskiej, Warszawa 1996 , s. 100.

3 Lietuvos Moksly Akademijos Biblioteka, Rankraščiu Skyrius (dalej LMAB), f. 40, nr 833 , s. 3-6.

4 Ilość 8 zborów istniejących w dystrykcie podlaskim wymienia w roku $1696 \mathrm{Krzy-}$ sztof Taubman-Trzebicki. Obraz historyczny kalwinizmu na Litwie 1650-1696, wyd. H. Barycz, „Reformacja w Polsce”, t. IV, s. 213.

5 H. Merczyng, Zbory i senatorowie protestanccy w Dawnej Rzeczypospolitej, Warszawa 1904 , s. 165 .

6 J. Łukaszewicz, Dzieje kościoła wyznania helweckiego w Litwie, Poznań 1842, t. II, s. 69,78 . 
fundowany w 1638 r. przez Piotra Kochlewskiego ${ }^{7}$, jednego z najbardziej zaufanych ludzi Krzysztofa II Radziwiłła, to okazuje się, że większość zborów podlaskich była fundowana przez Radziwiłłów lub przez ludzi blisko z nimi związanych, a rozprzestrzenianie się wyznania ewangelicko-reformowanego na Podlasiu było ewidentnie związane $z$ radziwiłłowską protekcją. Pozostałe zbory w dystrykcie podlaskim znajdowały się w Jamnie (fundacja Piekarskich(?)), Sidrze (fundacja Ostafiego Wołłowicza, kasztelana wileńskiego, kanclerza wielkiego litewskiego ${ }^{8}$ ) i w Niepokojczycach (fundacja Rajskich).

Losy radziwiłłowskich zborów podlaskich nie były jednakie. Większość z nich budowana była na tzw. „surowym korzeniu”. Wy jątek stanowi zbór w Węgrowie, gdzie wykorzystywano budynek kościoła katolickiego. W połowie XVI wieku Anna z Radziwiłłów Kiszczyna zamieniła kościół na zbór ewangelicki, potem na ariański. W roku 1569 Anna Kiszczyna odstąpiła dobra węgrowskie swemu synowi - Janowi, późniejszemu kasztelanowi wileńskiemu, i odtąd tamtejszy zbór miał nowego patrona. W 1592 roku zbór węgrowski i dobra węgrowskie znalazły się w posiadaniu wdowy po Kiszce, Elżbiety z Ostrogskich. W 1596 roku świątynia ta na powrót stała się kościołem katolickim, a to w wyniku ugody polubownej zawartej pomiędzy Elżbietą a jej drugim mężem Krzysztofem Radziwiłłem „Piorunem” - z jednej strony, a biskupem łuckim Bernardem Maciejowskim - z drugiej ${ }^{9}$. W tedy też zwrócono katolikom dobra kościelne. Elżbieta była córką Konstantego Wasyla Ostrogskiego - ostoi prawosławia w Rzeczypospolitej, ale też katoliczki - Zofii z Tarnowskich. Choć ochrzczona w cerkwi, wychowana została przez matkę w wierze katolickiej ${ }^{10}$. I temu wyznaniu pozostała wierna mimo małżeństwa $\mathrm{z}$ gorliwym protektorem arianizmu Janem Kiszką, kasztelanem wileńskim i wojewodą brzeskim, i mimo drugiego małżeństwa $z$ kalwinistą Krzysztofem Radziwiłłem. Radziwiłł starał się ograniczyć jej swobodę $\mathrm{w}$ kontaktowaniu się $\mathrm{z}$ duchownymi katolickimi ${ }^{11}$ i odciągnąc ją od jej katolickich praktyk, choć jedynie droga perswazji i to pośredniej, polecając swemu słudze Bartłomiejowiczowi „iżbyś w to mogąc najlepiej patrafiał,

7 Zbór w Nurcu założony został najprawdopodobniej w 1631 r. przez Piotra Piekarskiego, od którego Kochlewski go nabył. Z. Trawicka, Działalność polityczna i reformacyjna Piotra Kochlewskiego, „OiRwP” 1963, t. VIII, s. 141.

8 T. Wasilewski, Testament Ostafiego Wottowicza, „OiRwP”, t. VII, s. 167, 169.

9 J. Seredyka, Dzieje zatargów i ugody o kościót kiejdański w XVI-XVII w., „OiRwP” 1976 , t. XXI, s. 89.

10 T. Kempa, Konstanty Wasyl Ostrogski (ok. 1524/1525-1608), Toruń 1997, s. 91-92.

11 H. Lulewicz, Radziwitt Krzysztof zwany Piorunem h. Traby, w: PSB, t. XXX, z. 2, s. $274-275$. 
żeby małżonka nasza do kościoła nie jeździła" ${ }^{12}$. Kościół cały czas pozostawał katolicki, mimo iż Radziwiłł próbował usunąć stamtąd plebana, a kościół zamienić na zbór ewangelicki. Pleban nie dawał za wygraną i, chroniąc się w pobliskiej Starej Wsi, korzystał z okazji, aby zrywać kłódki i ponownie wyświęcać kościół ${ }^{13}$. Na dobrach węgrowskich Elżbieta z Ostrogskich miała zapisane po Kiszkach dożywocie i nie chciała tych dóbr przekazać Radziwiłłowi, co w latach 1596-97 doprowadziło do ostrych scysji między małżonkami. W konsekwencji po jej śmierci dobra te przejęli chwilowo jej bracia Janusz i Aleksander Ostrogscy. Dopiero po przejęciu przez Janusza Radziwiłła, podczaszego litewskiego dóbr węgrowskich, od książąt Ostrogskich ${ }^{14}$ kościół węgrowski z powrotem zamieniony został na zbór ewangelicko-reformowany. Ostatecznie Krzysztof II Radziwiłł jako prawny opiekun małoletniego bratanka Bogusława, zmuszony był jednak oddać katolikom budynek kościelny w Węgrowie, po czym zbudował tam dla kalwinistów w latach 1630-34 obszerną świątynię drewnian ą ${ }^{15}$, która zdaniem Gabriela Dyjakiewicza, seniora zborów podlaskich z początku XVIII wieku, była „aczci drewniana, ale bardzo wielka i porządna, na której wieży był i zegar wielki bijący na całe miasto" 16 . Najprawdopodobniej pozostałe zbory radziwiłłowskie na Podlasiu również były drewniane. W 1608 roku fundował on zbór kalwiński w Zabłudowie, który stanął w mieście między rynkiem a stawem dworskim, a jako dobry gospodarz zadbał o to, aby zbór zbudowany były porządnie i "chędogo". Choć zbór w Zabłudowie był drewniany, wg informacji danej Salomonowi Rysińskiemu w 1621 roku uposażony został placami w mieście i folwarkiem Rafałówka. Poza tym zbudowano tam szkołę i mieszkanie dla bakałarza, oprócz tego szpital i mieszkanie dla alumnów. Alumnów miało być czterech, a w szpitalu dziesięć miejsc dla ubogich. Ksiądz kaznodzieja

12 J. Grabowski, Radziwitłowie, Warszawa 1927, s. 6.

13 Powołuję się tutaj na ustną wypowiedź mgra Jarosława Zawadzkiego na Komisji Lituanistycznej w IH PAN w Warszawie w dniu 25 września 2002 r. Dziękuję też za wszelkie informacje udzielone mi na temat burzliwych losów kościoła węgrowskiego na przełomie XVI i XVII wieku.

14 Po wypłaceniu Ostrogskim 75 tys. zł, AGAD, AR, dz. XI, nr 36, s. 1, Wilno 30 czerwca 1614 r.; por. K. Niesiecki, Herbarz polski, Warszawa 1979, t. VII.

15 LMAB, f. 40, nr 359, k. 1. Wcześniej, bo już w 1627 roku Radziwiłł zmuszony był zwrócić katolikom kościół w Kiejdanach. Nie dziwi zatem zwrot kościoła węgrowskiego, wszak był to już przecież okres, w którym Stolica Apostolska zleciła przez nuncjusza biskupom polskim, aby tam gdzie nie uda się prawem - siłą odbierali utracone kościoły. Relacje nuncjuszów apostolskich i innych osób o Polsce, od 1548 do 1690, Berlin, Poznań 1864, t. II, s. 159.

16 T. Wyszomirski..., s. 139-140. 
dostawać miał dobre uposażenie i mieszkanie, aby przy okazji nie zajmował się czymś innym, gdyż „w paszczęce prawie adwersarzów siedzi i wszyscy nań oczy wytrzeszczyli". W 1620 (lub 1621) roku fundowany był zbór w Orli ${ }^{17}$.

Równolegle ze zborem budowano najczęściej szkołę. Krzysztof II ministrom w swoich dobrach nakazywał utrzymywanie bakałarzy dla nauczania dzieci wszystkich stanów. Synod, mając świadomość, iż „dobre ćwiczenie młodzi fundamentem jest całych Rzeczypospolitych" napominał patronów, aby pilnie doglądali szkół prowincjonalnych dystryktowych i patrykularnych oraz by w „dobrym porządku utrzymane i preceptorami przykładnemi i uczonemi pilnemi opatrzone były"18. Również Ludwika Karolina Radziwiłłówna, troszcząc się o edukację młodzieży, zalecała korzystanie ze wzorów niemieckich, holenderskich czy angielskich i radziła m.in., aby przy zborach organizować szkółki niedzielne dla dzieci i zatrudniać w szkołach kościelnych dobrze wykształconych nauczycieli - duchownych, zwolnionych od obowiązków duszpasterskich ${ }^{19}$. Jaki był poziom tych szkół nie wiadomo, a Łukaszewicz przestrzega, aby nie mieć tutaj wielkich złudzeń. Henryk Wisner pisze, że Janusz Radziwiłł, wojewoda wileński, mało interesował się szkołami ${ }^{20}$, ale w 1654 roku zdecydował się na przyjęcie propozycji synodu dotyczącej utworzenia w Zabłudowie gimnazjum i biblioteki dla młodzieży z prowincji litewskiej i małopolskiej. Szkoła pomyślana była jako wielkie przedsięwzięcie; na jej potrzeby Radziwiłł przeznaczył $1000 \mathrm{zł}$, książę Bogusław 6000 tysięcy, ponadto zbory prowincji litewskiej przeznaczyły 6000 , a zbory małopolskie $5000 \mathrm{z}^{21}$. Poza tym synod podejmował również kontrowersyjne, jak się wydaje, decyzje związane $z$ finansowaniem tej szkoły. Zdecydował bowiem „po długich deliberacjach”, aby 500 zł legowanych przez śp. p. Pakosławskiego na zbór w Sidrze przeznaczyć na szkołę zabłudowską ${ }^{22}$. Rektorem szkoły został ks. Krzysztof Pandłowski.

17 Lietuvos Nacionaline Biblioteka (dalej: LNB), f. 93, nr 73, s. 7.

18 LMAB, f. 40, nr 125, k. 14v, O szkołach in genere, $1653 \mathrm{r}$.

19 W. Kriegseisen, op. cit., s. 89.

20 H. Wisner, Janusz Radziwiłt, 1612-1655, wojewoda wilenski, hetman wielki litewski, Warszawa 2000, s. 228-229.

21 LMAB, f. 40, nr 125, k. 18v. 1654 r. Na utrzymanie powołanej w 1625 roku szkoły ewangelickiej w Kiejdanach Krzysztof II Radziwiłł i jego żona Anna z Kiszków przeznaczyli 25 tys. zł. Stanisław Tworek, Programy nauczania i prawa gimnazjum kalwińskiego $w$ Kiejdanach $z$ lat 1629 i 1685, „OiRwP” 1970, t. XV, s. 225.

22 LMAB, f. 40, nr 125, k. 21v. 1654 r. 
Rok później synod bardzo pozytywnie wypowiedział się na temat postępów w pracach przy budowie gimnazjum ${ }^{23}$. Założenia były ambitne i nie wiadomo jak potoczyłyby się dalsze losy szkoły, gdyby nie wojna. Być może stać się ona mogła poważną konkurencją dla tworzonych wówczas licznie kolegiów jezuickich ${ }^{24}$. Szkoła zabłudowska nigdy nie wyszła poza poziom minus, mimo iż zdaniem Ludwiki Karoliny jej utrzymanie to koszt niemały, a szkoła przecież mała i uczniów w niej niewiele. Podobnie jak szkoła kiejdańska, liczyła ona cztery klasy. Był to typ szeroko rozpowszechniony w szkolnictwie kalwińskim. Stanisław Tworek opublikował programy nauczania w gimnazjum kiejdańskim ${ }^{25}$. Biorąc pod uwagę podobny czy wręcz identyczny typ szkoły, wydaje się, że w Zabłudowie programy te mogły być jednakowe lub bardzo podobne. W roku 1685 szkoła ciągle posiadała cztery klasy, a w każdej od 6 do 8 uczniów. $Z$ wykazu uczniów wynika, iż naukę pobierali w niej nie tylko synowie miejscowej szlachty czy sług radziwiłłowskich, ale też potomkowie osiadłych tam Szkotów i Niemców ${ }^{26}$. Te same wnioski wypływają $\mathrm{z}$ badań Tworka nad gimnazjum kiejdańskim. Z inwentarza z 1688 roku wynika, że budynek szkolny, choć drewniany, był wówczas po remoncie, a jego stan był niezły. Inwentarz nie wspomina jednak nic o ewentualnej bibliotece przy szkole ${ }^{27}$. Radziwiłłówna przypuszczała, że łożone przez nią na cel edukacyjny pieniądze były marnotrawione. Wiadomo jej było również, iż studenci udający się potem do innych szkół czy akademii mieli fundamentalne braki w wykształceniu, a co gorsza nawet nie mogli zrozumieć gramatyki ${ }^{28}$.

Formalnie o zatrudnieniu $\mathrm{w}$ zborach radziwiłłowskich decydował synod. Często też $\mathrm{z}$ wnioskami personalnymi zwracały się do synodów zarządy poszczególnych zborów, proszące o podjęcie decyzji i skierowanie do pracy w zborze upatrzonego kandydata na kaznodzieję. Niekiedy dotyczyło

23 LMAB, f: 40, nr 125, k. 23, O seminarium zabłudowskim 1655 r.

24 Kolegium takie utworzono w 1660 r. w Drohiczynie (choć być może było już w 1653 roku), w Grodnie w 1641 r. i w pobliskiej Łomży w 1630 r. J. Łukaszewicz, Historia szkót $w$ Koronie $i w$ Wielkim Księstwie Litewskim od czasów najdawniejszych do roku 1794, Poznań 1851, t. IV, s. 62-64, 68-71, 109-110.

25 S. Tworek, Programy nauczania..., s. 232-236.

26 AGAD, AR, dz. VIII, nr 655, s. 12.

27 AGAD, AR, dz. VIII, nr 655, s. 51, 30 stycznia 1688 r.

28 LMAB, f. 40, nr 596, k. 59, Respons na instrukcję JMci księdza Minwida, superintendenta zawilejskiego od Synodu Prowincjonalnego do Najjaśniejszej Księżny Ludwiki Karoliny Radziwiłłówny, w Berlinie 30 listopada 1686 r. 
to nawet konseniorów, a więc zastępców superintendentów ${ }^{29}$. Zdarzało się, iż synod kierował się sugestiami Radziwiłłów, np. w 1663 roku skierowano do zboru węgrowskiego księdza Krasińskiego, nadwornego kaznodzieję Bogusława Radziwiłła ${ }^{30}$, bądź też - nie czekając na decyzję synodu - książę decydował sam, argumentując to zbyt długo utrzymującym się wakatem ${ }^{31}$. Środki przeznaczone na utrzymanie zborów składały się z kilku elementów i najczęściej były już wymienione w akcie fundacyjnym, np. dochody z folwarku Rafałówka i kilka placów w mieście Zabłudów, z których chłopi i niektórzy mieszczanie musieli pracować na potrzeby tamtejszego zboru. W przypadku Węgrowa - na utrzymanie zboru przeznaczono dochody ze wsi Szaruty, a z dochodów wsi Zuzołka utrzymywał się kaznodzieja starowiejski ${ }^{32}$. Kaznodzieja otrzymywał mieszkanie oraz wynagrodzenie w dwojakiej postaci: jurgieltu oraz uposażenia w naturze i stróża. Desygnowany przez synod kaznodzieja otrzymywał od Radziwiłła list do zarządców dóbr $\mathrm{z}$ informacją o wysokości uposażenia pieniężnego i naturalnego. Uposażenie to nie było jednakie dla wszystkich i, siłą rzeczy, zmieniało się w czasie, np. ksiądz Gutowski, kaznodzieja zabłudowski, otrzymywać miał w 1611 roku $100 \mathrm{zł} \mathrm{z}$ dochodów orlańskich (majętność zabłudowska pozostawała wówczas w arendzie) ${ }^{33}$, po pięćdziesięciu latach, w roku 1660 Bogusław Radziwiłł naznaczył księdzu Taubmanowi, kaznodziei zabłudowskiemu, również 100 złotych ${ }^{34}$. W związku z tym, że rok później Taubman pełnił również obowiązki kaznodziei orlańskiego, Radziwiłł polecił tamtejszym starostom, aby $\mathrm{z}$ każdej majętności wypłacali po 150 złotych $^{35}$. Jak się wydaje, od tego roku zbór zabłudowski i orlański miał wspólnego kaznodzieję. W tym samym roku książę z dochodów majętności starowiejskiej naznaczył 500 złotych księdzu plebanowi katolickiemu, a 600 złotych księdzu kaznodziei ewan-

29 W. Kriegseisen, op. cit., Warszawa 1996, s. 94.

30 LMAB, f. 40, nr 113, k. 8, Bogusław Radziwiłł do Władysława Starzyńskiego, z Królewca 5 marca 1663 r.

31 Po zajeździe Orli i Zabłudowa w 1660 roku, Bogusław Radziwiłł desygnował tam księdza Krzysztofa Taubmana, nie czekając na decyzję synodu, AGAD, AR, dz. IV (kopie), t. I, nr $4, \mathrm{k} .358 \mathrm{v}$.

32 LMAB, f. 40, nr 244, k. 12.

33 AGAD, AR, dz. VIII, nr 655, k. 1, Krzysztof Radziwiłł do Jana Głazowskiego, z Birż 5 czerwca $1611 \mathrm{r}$.

34 AGAD, AR, dz. IV (kopie), t. I, nr 4, k. 358v, Bogusław Radziwiłł do Krzysztofa Łopaty, z Hollandu 29 października 1660 r.

35 AGAD, AR, dz. VIII, nr 655, k. 7, Bogusław Radziwiłł do Krzysztofa Łopaty i Mikołaja Porębskiego, z Brandeburku 17 września 1661 r. 
gelickiemu ${ }^{36}$. Deklaracje nie zawsze znajdowały potwierdzenie w praktyce i zdarzało się, iż niekiedy przez kilka lat nie były wypłacane $z$ winy bądź to Radziwiłła, bądź też jego urzędników ${ }^{37}$. Ponadto skarb zborowy zasilany był przez legacje. Wiemy o takich sumach wpłacanych przez Szkotów węgrowskich na potrzeby tamtejszego zboru ${ }^{38}$. Niewykluczone zatem, że Szkoci mieszkający w dobrach zabłudowskich również czynili podobne legacje. Zbory podlaskie, już poważnie niedoinwestowane w pierwszej połowie XVII wieku, bardzo ucierpiały (wszystkie) w czasie wojny, rozkradziono naczynia zborowe, a meble często poprzenoszono do świątyń innych konfesji. $\mathrm{Z}$ informacji dla urzędników podlaskich wydawanych przez Bogusława Radziwiłła w 1661 roku wynika, że starał się on w jakiś sposób zapanować nad sytuacją, niekiedy dość oryginalnie. Otóż polecił Mikołajowi Porębskiemu, staroście orlańskiemu, aby okna, które właśnie wstawiono do cerkwi, wyjąć z niej i wstawić do zboru, a okna cerkwi zasłonić matami albo pozabijać deskami tak, aby szkody w cerkwi nie było ${ }^{39}$. Półśrodki oraz rozporządzenia, za którymi nie poszły żadne pieniądze, spowodowały, że w drugiej połowie XVII wieku podlaskie zbory sukcesywnie niszczały, a poza tym przcśladowania ewangelików znacznie się wzmogły. Synod, zdając sobie chyba sprawę $z$ tego, że na pomoc organizacyjną i finansową ze strony Radziwiłła za bardzo nie może liczyć, postanowił szukać pomocy materialnej i dyplomatycznej za granicą. Wysłano zatem do Anglii już w 1660 roku Jana Krzysztofa Krasińskiego, kaznodzieję węgrowskiego, człowieka wykształconego, powszechnie szanowanego, a przede wszystkim oddającego się z wielką ofiarnością i poświęceniem swym obowiązkom duszpasterskim. Misja Krasińskiego spo-

36 AGAD, AR, dz. IV (kopie), t. 2, nr 10, k. 9, 19 czerwca 1661 r. Dziwi trochę wysokość jurgieltu dla plebana katolickiego, bo w 1670 roku Wespazjan Sienicki, z dochodów majętności orlańskiej, wypłacał księdzu Krasińskiemu, kaznodziei węgrowskiemu, „tak jako za żywota księcia Jmci, tak i teraz" - 700 zł, ks. Taubmanowi, kaznodziei orlańskiemu - 150 zł, ks. plebanowi zabłudowskiemu - 100 zł, ks. kaznodziei saskiemu - 150 zł (AR, VIII, nr 65, s. 10). Z dokumentu erekcyjnego zboru węgrowskiego wynika, że desygnowany tam ksiądz ewangelicki, Jan Węgrowski, na mocy decyzji Krzysztofa II Radziwiłła otrzymywać miał jurgielt w wysokości 200 złotych (LMAB, f. 40, nr 359, k. 1, 1630 r.).

37 U. Augustyniak, Duchowni klienci Krzysztofa Il Radziwiłła. Kondycja i funkcje duchowieństwa ewangelicko-reformowanego w dobrach radziwittowskich $w$ pierwszej potowie XVII wieku, "Miscellanea Historico-Archivistica”, t. III, Radziwitłowie XVI-XVIII wieku: w kręgu polityki i kultury, Warszawa-Łódź 1989, s. 161-163.

38 LMAB, f. 40, nr 113, dokument 10, s. 21, 17 lutego 1667 r.

39 AGAD, AR, dz. IV (kopie), t. I, nr 8, s. 599, Informacja Mikołajowi Porębskiemu, z Zabłudowa 3 kwietnia $1661 \mathrm{r}$. 
tykała się z uznaniem synodu, stąd też kilkakrotnie jeszcze wysyłano go za granicę ${ }^{40}$.

W maju 1664 roku Bogusław Radziwiłł, targany rozlicznymi kłopotami finansowymi, sprzedał majętność starowiejsko-węgrowską Janowi Kazimierzowi Krasińskiemu, podskarbiemu wielkiemu koronnemu, wyłączając jednakże $\mathrm{z}$ aktu sprzedaży 16 morgów gruntu, na którym znajdował się zbór ewangelicki, szkoła, szpital, poza tym mieszkanie ministra kalwińskiego i pastora luterańskiego. W akcie sprzedaży zastrzegł też wszelkie swobody religijne dla ludności ewangelickiej, a także prawo do swobodnego przemieszczania kupców niemieckich i szkockich dotąd w Węgrowie mieszkających $^{41}$. Sprawa zmiany właściciela dóbr na gorliwego katolika niewątpliwie niepokoiła ewangelików węgrowskich. W 1664 roku kaznodzieja węgrowski, Jan Krzysztof Krasiński, referował synodowi swoją rozmowę z Radziwiłłem, z której wynikało, że książę w związku z zaistniałą sytuacją obiecał bądź to fundować nowy zbór na granicy pruskiej, bądź też legować sumę $6000 \mathrm{zł}$ na zbór węgrowski i jego utrzymanie. Nie wiemy, na ile synod poważnie potraktował obietnicę księcia, w każdym razie zdecydował się podziękować, gdyby ten wywiązał się $\mathrm{z}$ obietnic ${ }^{42}$. Z późniejszej supliki (1670) kierowanej przez seniorów tegoż zboru do Teofila Dunin Rajeckiego, marszałka lidzkiego, dawnego zaufanego sługi Bogusława Radziwiłła, wynika, że Radziwiłł sprzedał Krasińskiemu ponadto 3 włóki osiadłe, od dawna należące do zboru, za które dodatkowo otrzymał trzy tysiące złotych. Z wydanej asekuracji wynikało, że z pieniędzy tych corocznie wpłacać miał do kasy zboru odpowiednią ratę. Ponownie skończyło się tylko na deklaracjach ${ }^{43}$. Poza tym Radziwiłł już wcześniej pożyczył z kasy zborowej 950 zł ${ }^{44}$. Te pieniądze ewangelicy węgrowscy odzyskali, ale dopiero po wielokrotnych monitach w roku 1681 (w dziesięciu ratach) od zarządców dóbr Ludwiki Karoliny ${ }^{45}$. Notabene, pieniądze zborowe nie były chyba najlepiej zarządzane, a rozpożyczano je nazbyt lekką ręką, Radziwiłł bowiem nie był wówczas jedynym

40 AGAD, AR, dz. VIII, nr 713, k. 354v, 378v, LMAB, f. 40, nr 125, k. 60v.

41 Lietuvos Nacionalinis Muziejus, rkps 893, k. 98-99.

42 LMAB, f. 40. nr 125, k. 44v, Akta synodu z 1664 r. pkt 8.

43 LMAB, f. 40, nr 113, k. 10, Węgrów 19 marzec 1670 r.

44 AGAD, AR, dz. VIII, nr 602, k. 1.

45 Lietuvos Vastybès Istorijos Archyvas (dalej LVIA), f. 1280, nr 2128, k. 27v, LMAB, f. 40, nr 125, k. 133v, AGAD, AR, dz. VIII, nr 602, s. 23, 27. 
dłużnikiem zboru ${ }^{46}$. Wyłączanie $\mathrm{z}$ aktu sprzedaży czy zastawu budynków i terenów należących do kościołów różnych wyznań było powszechną praktyką. Podobnie do ojca postępowała Ludwika Karolina, np. w 1694 roku, kiedy to zastawiła na trzy lata dobra orlańskie Benedyktowi Pawłowi Sapieże $^{47}$. Z aktu zastawu wyłączyła wówczas m.in. zbór orlański, a Sapieha zobowiązał się ,że zbór ewangelicki w miasteczku Orlu będący ze wszystkimi do niego przynależnościami, z placami i z ostającemi na nich mieszkańcami tudzież samego kaznodzieję zborowego $\mathrm{z}$ domowemi jego w protekciej mojej i dworu orleńskiego mieć od wszelkich impetycji, zaszczycać tak aby sam kaznodzieja w pokoju i bezpieczeństwie wszelkiem zostawał" 48. Taka forma zapisu pozwalała na utrzymanie przez Radziwiłłów zarówno praw jak i obowịąków kolatorskich ${ }^{49}$.

Zdaniem Krzysztofa II Radziwiłła, ludność poddana nie jest zdolna stanowić o sobie, stąd troska o jej zbawienie należy do pana ${ }^{50}$. W związku z tym dziesiętnicy i setnicy doprowadzać ich mieli na nabożeństwo zborowe, a opornych karać grzywną ${ }^{51}$. Zarówno teoria jak i zalecenia w przypadku magnata wykształconego na zachodnioeuropejskich protestanckich uniwersytetach nie dziwi, gdyż była ona typowa dla zachodnioeuropejskiej doktryny kalwińskiej ${ }^{52}$. Dała ona jednak historykom podstawę do przypuszczeń bądź twierdzeń, że nie tylko Radziwiłł, ale i inna bogata litewska szlachta kalwińska w swoich dobrach stosowała się do zasady cuius regio

46 LMAB, f. 40, nr 125, k. 45v, Akta Synodu z 1664 r., pkt 4.60 zł zborowi węgrowskiemu był winien dawny starosta starowiejski Jan Cedrowski. Por. T. Wyszomirski, Z przeszłości zboru protestanckiego w Wegrowie w XVII i XVIII wieku, „OiRwP” 1959, t. IV, s. 145.

47 NHAB, f. 694, op. 4, nr 1035, k. 19.

48 LMAB, f. 40, nr 462, Wilno 12 kwietnia 1694 r.

49 Prawo to wykorzystywała Ludwika Karolina nie tylko w wymienianych w tekście Węgrowie czy Orli, ale też w stosunku do plebana katolickiego w Sielcu (AGAD, AR, dz. VIII, nr 498, s. 1-2), tamtejszego pastora luterańskiego (AGAD, AR, dz. VIII, nr 499), czy kaznodziei kalwińskiego (AGAD, AR, dz. VIII, nr 499, s. 13).

50 H. Wisner, Radziwitt Krzysztof, h. Traby, w: PSB, t. XXX, z. 2. s. 281.

51 J. Tazbir, Reformacja w Polsce. Szkice o ludziach i doktrynie, Warszawa 1993, s. 119; U. Augustyniak, Dwór i klientela Krzysztofa Radziwitła (1585-1640), Warszawa 2001, s. 47; H. Wisner, Krzysztof II Radziwitt (1585-1640), Warszawa 1967, maszynopis pracy doktorskiej w Bibliotece Wydz. Hist. UW, sygn. P.Dr XIa, 11094, s. 9.

52 F. Lebrun, Reformacja: wspólna wiara i osobista pobożność, w: Historia życia prywatnego, t. 3, Od renesansu do oświecenia, pod red. Rogera Chartiera, Wrocław 1999, s. 112; M. Weber, Etyka protestancka a duch kapitalizmu, Lublin 1994, s. 21. 
eius religio ${ }^{53}$. Zarządzenia te $\mathrm{w}$ praktyce realizowane były $\mathrm{z}$ powodzeniem w Księstwie Birżańskim ${ }^{54}$, ale nie wydaje się, aby mogły być stosowane w dobrach podlaskich, choćby $\mathrm{z}$ racji na mieszkanie obok siebie ludzi różnych wyznań. W podlaskich miasteczkach radziwiłłowskich zbór protestancki często sąsiadował z kościołem katolickim bądź cerkwią prawosławną czy unicką. Miejscowe duchowieństwo katolickie i prawosławne wysuwające pod adresem Radziwiłłów różne pretensje, najczęściej natury ekonomicznej, nigdy jednak nie używało tego argumentu. Nie ulega wątpliwości, że wyznanie protestanckie traktowane było tam przez właścicieli jako najważniejsze. Kiedy w 1643 roku Janusz Radziwiłł wydał przywilej odnawiający prawa miejskie dla Orli, zmienił wówczas czas odbywania targów ze środy na niedzielę, zaznaczając jednakże „aby nie targowali nic aż się nabożeństwo w zborze odprawi" 55 .

Radziwiłłowie kontrolowali też życie moralne poddanych, a w przypadku nieprawidłowości stwierdzonych przez zarządców dóbr, ci ostatni wespół z duchownymi starać się mieli o ich odnowę moralną. Już Janusz Radziwiłł, podczaszy litewski, przypominał parafianom o obowiązku chrzczenia dzieci i zawierania związków małżeńskich we własnych parafiach ${ }^{56}$. Z badań Rafała Degiela dotyczących ludności prawosławnej w księstwie słuckim wynika, że opiekunowie Ludwiki Karoliny w 1691 roku wprowadzili tam swoisty przymus religijny dotyczący poddanych „dla zbawienia dusz onych". Polegać on miał na obowiązkowym uczestnictwie we mszy świętej, komunii i spowiedzi. Osoby uchylające się, podobnie do poddanych w księstwie birżańskim, miały płacić karę pieniężną. Obywatele miasta Słucka w każdą niedzielę i święta mieli posyłać swoją czeladź na mszę i dla uczenia się pacierza. Podobnie jak w Birżach, nadzór nad życiem religijnym poddanych

53 Tworek, poza Krzysztofem Radziwiłłem „Piorunem” i jego synem Krzysztofem II, wymienia jeszcze jednego magnata: Eustachego Wołłowicza, kasztelana wileńskiego i kanclerza litewskiego, oraz dwie osoby z kręgu bogatej szlachty litewskiej: Zofię z Mitkiewiczów Wnuczkową, marszałkową i ciwunową retowską, i Zofię z Radzymińskich Grużewską. S. Tworek, Przymus wyznaniowy na terenie Wielkiego Księstwa Litewskiego w XVI-XVII w., „OiRwP” 1974, t. XIX, s. 161-164.

$54 \mathrm{Za}$ informacje na ten temat dziękuję dr. Deimantasowi Karvelisowi z Uniwersytetu Pedagogicznego w Wilnie.

55 Archiwum Państwowe w Białymstoku (dalej: APB), Kamera Wojny i Domen w Białymstoku, sygn. 2899, k. 48.

56 R. Degiel, Protestanci i prawostawni. Patronat wyznaniowy Radziwittów birżanskich nad Cerkwia prawostawna w księstwie słúckim w XVII w., Warszawa 2000, s. 100. 
sprawować mieli dziesiętnicy - tutaj wespół ze świaszczennikami ${ }^{57}$. Nic nie słychać o próbach wprowadzenia podobnego procederu w dobrach podlaskich.

\section{Ewangelicy augsburscy}

W 1650 roku utworzono w Węgrowie parafię ewangelicko-augsburską. Poprosili o to Bogusława Radziwiłła mieszczanie warszawscy pozbawieni na Mazowszu możliwości publicznego odprawiania nabożeństwa. W specjalnym przywileju wydanym w roku 1651 książę przeznaczył ze swych funduszów 300 zł na utrzymanie duchownego luterańskiego. Obydwa zbory protestanckie korzystały z jednej świątyni, a zasady korzystania $z$ niej uregulowano 14 maja 1653 roku specjalną umową zawartą między ministrem Maciejem Apollosem Styrzyńskim a pastorem Janem Columbusem ${ }^{58}$. Przywilej integralnie związany był z innym, wydanym 14 kwietnia 1650 r. dla wszystkich cudzoziemców, a szczególnie kupców i rzemieślników wyznania ewangelickiego, zarówno genewskiego jak i augsburskiego, chcących osiedlić się w Węgrowie. Obiecywał tam Radziwiłł wszelkie swobody i wolności, a także pomoc przy zakładaniu szkół, szpitali, etc. ${ }^{59}$ Dwa lata wcześniej (pod nieobecność Radziwiłła w Rzeczypospolitej) w Węgrowie miały miejsce dość burzliwe wystąpienia katolików przeciw ewangelikom, kiedy to mocno poturbowano ówczesnego ministra i jednocześnie wybitnego teologa, Macieja Apollosa Styrzyńskiego ${ }^{60}$. Celem Radziwiłła mogło być zatem nie tylko ściągnięcie do miasta osadników, ale też wzmocnienie miejscowej, mocno już wówczas przerzedzonej i osłabionej gminy protestanckiej. Nie wiemy, na ile świadomie realizował tu złożenia swojego stryja Krzysztofa, polegające na tym, aby przy tego rodzaju działaniach motywy ekonomiczne łączyć z ideowymi ${ }^{61}$. Nabożeństwa luterańskie odbywały się po niemiecku, w przeciwieństwie do kalwińskich odprawianych wyłącznie po polsku. W później-

57 R. Degiel, op. cit., s. 101-102.

58 AGAD, AR, dz. VIII, nr 602, k. 5, 7-9.

59 LMAB, f. 40, nr 113, k. 7. Podobny w treści przywilej uzyskali 18 marca 1662 roku cudzoziemcy nacji szkockiej w Zabłudowie. Prawa $i$ przywileje miasta $i$ dóbr ziemskich Zabłudów XV-XVIII w., oprac. J. Maroszek, Białystok 1994, dok. nr 31, s. 213.

60 LMAB, f. 40, nr 359, k. 2, Węgrów 3 kwietnia 1648.

61 Por. U. Augustyniak, Dwór i klientela..., s. 61. 
szym okresie luteranie mieli jednak kłopoty z pozyskaniem do Węgrowa pastora znającego język niemiecki ${ }^{62}$. Stosunki między luteranami a kalwinami, korzystającymi ze wspólnego zboru, nie zawsze układały się pomyślnie i harmonijnie. Sama obecność obcych wyznaniowo i obdarzonych dodatkowymi przywilejami cudzoziemców najwyraźniej jednak nie przeszkadzała mieszkańcom miasteczek radziwiłłowskich na Podlasiu, skoro w 1684 roku mieszkańcy Zabłudowa na swojego burmistrza wybrali Szkota - Davida Nesmeta $^{63}$. Wspominany wcześniej fakt sprzedaży Węgrowa gorliwemu katolikowi zaniepokoił luteran. 17 maja 1667 roku zwrócili się oni z supliką do Bogusława Radziwiłła, aby spowodował legalne uznanie ich drugiego kaznodziei, co spotkało się z bardzo chłodną reakcją księcia. Wydaje się, iż mogła ona wynikać z obawy, aby zagwarantowanie uprawnień luteranów nie pogorszyło sytuacji zboru kalwińskiego ${ }^{64}$. Po śmierci ojca, Ludwika Karolina w 1687 roku deklarowała 400 złotych na utrzymanie kaznodziei luterańskiego ${ }^{65}$ oraz wydała kilka przywilejów, w których potwierdziła prawo do korzystania ze zboru węgrowskiego przez mieszkańców Warszawy wyznania luterańskiego, zatwierdziła uposażenie zboru nadane przez Krzysztofa i Bogusława Radziwiłłów. Dozór i opiekę nad zborem przekazała zaś nie swym sukcesorom, lecz „patronom, dozorcom i starszym zborów ewangelickich w Wielkim Księstwie Litewskim". Wydaje się, że powodem takiego zapisu był fakt, iż dzieci Radziwiłłówny ${ }^{66}$ wychowywane były w wierze katolickiej, a jej mąż Karol Filip Wittelsbach, książę neuburski, nie posiadał w Rzeczypospolitej indygenatu. Dochód kościoła kalwińskiego w Węgrowie został zabezpieczony na dobrach zabłudowskich ${ }^{67}$. Potwierdziła uposażenie zboru zabłudowskiego ${ }^{68}$. Na dobrach zabłudowskich z kolei zapisała 27 tysięcy zł zborom: węgrowskiemu, orlańskiemu i zabłudowskiemu

62 W. Kriegseisen, op. cit., s. 120.

63 Prawa i przywileje miasta $i$ dóbr Zabtudów..., dok. nr 42, s. 237-238, Zabłudów 24 czerwca $1684 \mathrm{r}$.

64 T. Wyszomirski, Zbór protestancki..., s. 146.

65 AGAD, AR, dz. XI, nr 54, k. 144-147, Berlin 5 sierpnia 1687 r.

66 Wiek dorosły osiągnęła tylko córka Elżbieta Augusta, od 1717 roku żona Józefa Karola Emanuela Wittelsbacha, księcia Sulzbach.

67 T. Wyszomirski, Zbór protestancki..., s. 150, Berlin 5 sierpnia 1687 r., Brzeg 27 października 1693 r.

68 AGAD, AR, dz. VIII, nr 655, s. 23-37, druk: Prawa i przywileje miasta $i$ dóbr Zabłudów..., dok. 51, s. 255-258, Berlin 12 grudnia 1687 r. 
oraz zborowi luterańskiemu w Węgrowie ${ }^{69}$. Tego samego dnia uposażyła ona też inne zbory fundacji radziwiłłowskiej na terenie Wielkiego Księstwa Litewskiego $^{70}$.

\section{Arianie}

Na Podlasiu jeden zbór ariański istniał już w 1558 roku w Węgrowie, kiedy to Anna z Radziwiłłów Kiszczyna na potrzeby tegoż przejęła budynek kościoła katolickiego (wbrew edyktowi Zygmunta Augusta sprzed roku zabraniającego wszelkich zmian w stanie posiadania Kościoła katolickiego). Od momentu pojawienia się w Węgrowie Piotra z Goniądza (1563 r.), zdaniem Wyszomirskiego, zbór ten możemy uważać za zbór ariański ${ }^{71}$. I takim pozostał do czasu, kiedy włość węgrowska przypadła wdowie po Janie Kiszce Elżbiecie z Ostrogskich. Drugi ze zborów znajdował się już poza dobrami radziwiłłowskimi w Surażu, a utworzony został w 1590 roku przez tamtejszego starostę Pawła Orzechowskiego, podkomorzego chełmskiego. Po jego śmierci w 1612 roku zbór najprawdopodobniej przestał istnieć ${ }^{72}$. Zdaniem Janusza Tazbira, jedynym Radziwiłłem darzącym arian sympatią był Mikołaj Radziwiłł „Czarny”, a wynikała ona z magnackiej fantazji człowieka szukającego „prawdy bożej” w możliwie nieskażonej postacip3. Janusz Radziwiłł, podczaszy litewski, mimo iż w czasie układania artykułów zjazdu sandomierskiego 29 sierpnia 1606 roku poparł wniosek o wyłączenie arian z postanowień o pokoju religijnym, to wyjeżdżając 27 lipca 1609 roku ze Starej Wsi i opuszczając kraj, zarząd swych dóbr pozostawił m.in. arianinowi Samuelowi Grądzkiemu ${ }^{74}$. Z kolei Krzysztof II, choć formalnie nie zgadzał się na obecność arian i propagandę arianizmu w dobrach radziwiłłowskich, to miał na swym dworze i wśród najbardziej zaufanych ludzi wielu arian. Samuel Przypkowski, Stanisław Buczyński czy Stanisław Kurosz, mieszkając wiele lat w dobrach podlaskich, oddawali mu wiele usług. Ten ostatni w czasie sejmów: 1625, 1626, 1627 roku reprezentował

69 AGAD, AR, dz. VIII, nr 655, s. 19-22, nr 709, s. 36-48, Berlin, 20 czerwca 1687 r.

70 AGAD, AR, dz. VIII, nr 709, s. 18-20.

71 T. Wyszomirski, $Z$ przesztości..., s. 137.

72. S. Tworek, Orzechowski Pawet, herbu Rogala, w: PSB, t. XXIV, z. 1, s. 284.

73 J. Tazbir, Reformacja w Polsce. Szkice o ludziach $i$ doktrynie, Warszawa 1993, s. 128 .

74 T. Wasilewski, Radziwitt Janusz, h. Traby, w: PSB, t. XXX, z. 2, s. 205-206. 
księcia w kontaktach $\mathrm{z}$ senatorami, m.in. $\mathrm{z}$ prymasem, niekiedy w spra-' wach bardzo drażliwych, np. w konfliktach z klerem katolickim o plebanie w Słucku i w Kiejdanach ${ }^{75}$. Na podstawie listu Kurosza do Radziwiłła, piszącego o tym, że „ministrowie naszy we dworze podług pierwszego pozwolenia Waszej Książęcej Mości nauki odprawią, a we zborze minister ewangelicki". Tazbir przypuszcza, że książę przy przyjmowaniu na służbę udzielił mu zezwolenia na urządzanie nabożeństw ariańskich $\mathrm{w}$ domu ${ }^{76}$. Nie wiadomo jednak, czy szło tutaj wyłącznie o jednorazowe nabożeństwo za duszę zmarłej właśnie pierwszej żony Kurosza, czy też była to stała zgoda. Kurosz powtórnie ożenił się rok później z Jadwigą Grekówną, przedstawicielką jednej z nielicznych miejscowych szlacheckich rodzin ariańskich, oddającej swe usługi Radziwiłłom. Grekowie pełnili urzędy na Podlasiu do roku 1660, kiedy dwaj przedstawiciele rodu zostali zmuszeni do zrzeczenia się ich „za arianizm"77. To, co prawda, jeden z nielicznych przykładów, ale przeczących teorii Jana Glinki, że wyznawcy arianizmu na Podlasiu to chłopi i mieszczanie, a szlachta stanowiła tu element wyłącznie napływowy ${ }^{78}$. Janusz Radziwiłł, wojewoda wileński, przejmując po ojcu administrację dóbr zwalniał spośród sług ojca tych, którzy wyznawali arianizm, ponadto wsławił się zdaniem „wiarą ich podobno bardziej niżeli się oni moją brzydzę"79. Konsekwentny w tej materii jak wszyscy Radziwiłłowie, na uroczystość zaręczyn z hospodarówną Marią (zwaną później Wołoszką), gorliwą wyznawczynią prawosławia, wysłał m.in. Jana Mierzeńskiego, arianina ${ }^{80}$. Najwyraźniej rozprawienie się $\mathrm{z}$ arianizmem pozostawił zgodnie $\mathrm{z}$ wcześniejszą deklaracją Bogu. Mierzeński stał się potem jednym z najbliższych współpracowników Bogusława Radziwiłła. On i jego brat Samuel dzierżawili należące do klu-

75 U. Augustyniak, Znaczenie więzów krwi w systemach nieformalnych w Rzeczypospolitej pierwszej połowy XVII wieku na przykładzie klienteli Radziwiłtów birżańskich, w: Kultura staropolska - kultura europejska. Prace ofiarowane Januszowi Tazbirowi w siedemdziesiąta rocznicę urodzin, Warszawa 1997, s. 208.

76 AGAD, AR, nr 8080, t. 173, s. 126, Stanisław Kurosz do Krzysztofa Radziwiłła z Orli, 29 kwietnia 1630 r.; J. Tazbir, Arianie w Biatymstoku i okolicach, w: Studia i materiały do dziejów miasta Białegostoku, Białystok 1968, s. 88.

77 Stefan Grek, podczaszy mielnicki (6 październik 1660 r.), i nieznany z imienia Grek, cześnik mielnicki (30 lipiec 1661 r.), zostali zmuszeni do ustąpienia z urzędów za arianizm. Urzędnicy podlascy XIV-XVIII wieku, oprac. E. Dubas-Urwanowicz, W. Jarmolik, M. Kulecki, J. Urwanowicz, Kórnik 1994, s. 103, 111; A. Boniecki, Herbarz polski, t. VII, s. 55.

78 J. Tazbir, Arianie w Biatymstoku..., s. 84.

79 H. Wisner, Najjaśniejsza Rzeczypospolita, Warszawa 1978, s. 147.

80 T. Wasilewski, Radziwitt Janusz, h. Traby, w: PSB, t. XXX, z. 2, s. 210. 
cza zabłudowskiego Niewodnicę i Dojlidy. Trzeci z braci, Aleksander, również pozostawał w służbie radziwiłłowskiej. W kluczu zabłudowskim w 1662 roku mieszkało około $50 \operatorname{arian}^{81}$, mimo konstytucji sejmowej z 20 lipca 1558 roku nakazującej im zmianę wyznania bądź wyprzedanie w ciągu trzech lat (czyli do 1661 r.) majątków i opuszczenie kraju ${ }^{82} .22$ marca 1659 roku edykt banicji połączono z zastrzeżeniem, iż arianie mogą tylko za cenę przyjęcia katolicyzmu (a nie kalwinizmu) pozostać w Polsce. Zakaz konwersji arian na kalwinizm uchwalił też Synod Jednoty Litewskiej ${ }^{83}$. Jan Kazimierz, godząc się na podobną uchwałę, wypełniał, co prawda, ślub złożony we Lwowie (1 kwietnia 1656 r.), ale pamiętać trzeba, że nigdy nie został fanatycznym prześladowcą arian. Para królewska udzieliła im nawet schronienia w swych posiadłościach na Śląsku Opolskim ${ }^{84}$. Poza tym, znamienne jest to, że dzierżawy dóbr radziwiłłowskich przez arian nie wzbudzały protestów miejscowej szlachty. Na sejmie w 1661 roku, kiedy to Radziwiłł występował przeciwko konstytucji o arianach, wspierał go bardzo energicznie miejscowy szlachcic, a jednocześnie zaufany sługa Krzysztof Żelski, pisarz ziemi bielskiej ${ }^{85}$. Nie wiadomo zatem, jak długo udałoby się arianom pozostać w dobrach podlaskich Radziwiłłów, gdyby nie ksiądz Wieczorkowski, pleban zabłudowski. Żądał on usunięcia arian, powodowany zapewne gorliwością religijną, choć niemniej żarliwie pożądał ich majątków, co gwarantowała mu konstytucja sejmowa. Wystosował pozew przeciw Radziwiłłowi o zaległą dziesięcinę i przechowywanie w swoich dobrach arian wbrew konstytucjom sejmowym. Nie czekając na rozprawę, najechał z ośmioma ludźmi folwark Białostoczek, faktycznie zamieszkiwany przez arian, co później barwnie opisał w liście do Radziwiłła dzierżawca Mikołaj Błoński ${ }^{86}$. W sumie jednak arianie opuścili dobra zabłudowskie, udając się głównie do Prus Książęcych, gdzie Radziwiłł, wykorzystując swoje dobre stosunki z elektorem, wystarał się dla wielu z nich o azyl. Za jego protekcją Zbigniew Morsztyn i Samuel Przypkowski

81 AGAD, AR, dz. II, nr 1458, s. 1-2, Pozew Faustyna Wieczorkowskiego do Bogustawa Radziwitta za przechowywanie arian, 21 czerwca $1662 \mathrm{r}$.

82 J. Tazbir, Bracia polscy na wygnaniu. Studia z dziejów emigracji ariańskiej, Warszawa 1977, s. 66 .

83 LMAB, f. 40, nr 125, k. 36v, 1661 r.

84 T. Wasilewski, Ostatni Waza na polskim tronie, Katowice 1984, s. 195, 216; J. Tazbir, Bracia polscy..., s. 61-62.

85 AGAD, AR, dz. IV (kopie), t. I, nr 3, k. 344; Bogusław Radziwiłł, Autobiografia, oprac. T. Wasilewski, Warszawa 1979, s. 146-147.

86 AGAD, AR, dz. V, t. 22, nr 922, list 2. 
otrzymali zatrudnienie na dworze królewieckim, a Józef Naroński w zarządzie dóbr elektorskich ${ }^{87}$. Zdaniem Janusza Tazbira to nie wdzięczność za wyświadczone usługi kierowała tu księciem, ale przede wszystkim nadzieja na korzystanie $\mathrm{z}$ ich usług $\mathrm{w}$ dalszym ciągu ${ }^{88}$. Warto tu dodać, że np. Mikołaj Błoński powrócił pod koniec życia do Polski i osiadł w Sobolewie na Podlasiu, gdzie otrzymywał za pośrednictwem Stanisława Niezabitowskiego, zarządcy dóbr radziwiłłowskich uposażenie od Ludwiki Karoliny ${ }^{89}$.

\section{Katolicy}

Struktura Kościoła katolickiego na Podlasiu podzielona była między dwie diecezje: łucką i wileńską, tak więc radziwiłłowska w XVII wieku Orla i dobra starowiejsko-węgrowskie należały do archidiakonatu brzeskiego diecezji łuckiej (Węgrów był stolicą dekanatu), a klucz zabłudowski do diecezji wileńskiej ${ }^{90}$. W dobrach radziwiłłowskich na Podlasiu były w tym czasie trzy kościoły parafialne katolickie: $\mathrm{w}$ Węgrowie $\mathrm{z}$ filią w Starej Wsi (i jednym małym kościółkiem na przedmieściu Węgrowa - istniał w II poł. XVII w.), w Sokołowie $^{91}$ i Zabłudowie. Po wejściu na Podlasie Radziwiłłowie zastali tam już ukształtowaną strukturę parafialną istniejącą od XV wieku. Obecne na terenie ich dóbr kościoły dalej istniały, a księża dalej prowadzili działalność ekumeniczną. Wy jątek stanowi kościół w Węgrowie dopiero w 1630 roku zwrócony katolikom. Zachowali oni po poprzednich właścicielach kosztowne niekiedy uprawnienia kolatorskie nad kościołami grecko- i rzymskokatolickimi, które dawało m.in. „prawo prezenty”, czyli przedstawiania biskupowi kandydata na wakujące beneficjum przy kościele. Dawało to przynajmniej w teorii możliwość zapewnienia sobie uległego plebana, ale z drugiej strony zobowiązywało do przestrzegania przywilejów nadanych przez dawnych patronów, m.in. do przekazywania dziesięciny do parafii katolickiej. Z inwentarza plebanii węgrowskiej z 1619 r. wynikało, że „na jej trzymanie mieszczanie

87 T. Wasilewski, Radziwitt Bogustaw, h. Traby, w: PSB, t. XXX, z. 1, s. 169.

88 J. Tazbir, Bracia polscy..., s. 58.

89 J. Tazbir, Arianie w Białymstoku..., s. 96.

90 B. Kumor, Granice metropolii i diecezji polskich (968-1939), „Archiwa, Biblioteki i Muzea Kościelne" 1969, t. XIX, s. 292-295, 347-351.

91 A. Laszuk, Zaścianki i królewszczyzny. Struktura własności ziemskiej w województwie podlaskim w drugiej połowie XVII wieku, Warszawa 1998, s. 109, 111, 113, 114. 
i chłopi węgrowscy płacą dziesięcinę" 92. Poza tym księża katoliccy, podobnie do ministrów protestanckich otrzymywali od patronów jurgielt ${ }^{93}$. Tak miało być, choć patroni nie zawsze wywiązywali się ze wcześniejszych deklaracji dotyczących Kościoła katolickiego. Stąd np. plebania zabłudowska w I połowie XVII wieku często pozostawała bez plebana. Z wizytacji przeprowadzonej w 1633 roku wynika, iż z powodu nieobecności proboszcza dzieci chrzczą "popi schizmatycy" 94. Zbyt długie wakaty w parafiach katolickich w sumie przysporzyły Radziwiłłom największych problemów. W 1652 roku wakującą parafię węgrowską objął Jan Uszyński, scholastyk łucki, a kiedy starosta starowiejsko-węgrowski Radziwiłła, Jan Niewiarowski, późniejszy podczaszy kaliski, usunął go siłą z plebanii, nieco tylko poturbowawszy, skończyło się to dla księcia długim i kosztownym procesem. Radziwiłł tłumaczył się potem, że ksiądz nie posiadał od niego patrona, prezenty, a poza tym zastrzelił mu dwóch żołnierzy siedząc w browarze. Biskup łucki Andrzej Gembicki nie przyjmował takich tłumaczeń, sprawa stanęła na Trybunale Piotrkowskim, gdzie książę wspierany przez kuzyna, Władysława Dominika Zasławskiego-Ostrogskiego „personaliter stawać musiał i stawiać z pięćdziesiąt świadków szlachty", co miało go kosztować ponad osiemdziesiąt tysięcy złotych ${ }^{95}$. Radziwiłł postawił jednak na swoim i usunął Uszyńskiego $\mathrm{z}$ plebanii, nie za darmo jednak. Musiał mu za to zapłacić 14 tysięcy ${ }^{96}$. Podobny w pewnym sensie spór toczył Radziwiłł ze wspomnianym już księdzem Faustynem Wieczorkowskim, dziekanem smoleńskim, choć sprawa przybrała tutaj znacznie szerszy wymiar. Po pierwsze: Wieczorkowski zajął zbrojnie parafię zabłudowską posiadającą wówczas plebana, ale zrobił to w roku 1657, kiedy Radziwiłł $\mathrm{z}$ oczywistych względów nie mógł interweniować, a po drugie biskup wileński zatwierdził jego osobę mimo oczywistej samowoli ${ }^{97}$. Po zajeździe Zabłudowa i Orli Radziwiłł próbował usunąć Wieczorkowskiego, prezentu-

92 LMAB, f. 40, nr 113, Inwentarz plebanii węgrowskiej księdza Mikołaja Benisławskiego, sporządzony przez Mikołaja Radzyńskiego, sługę księcia Janusza Radziwiłła, kasztelana wileńskiego, 5 listopada $1619 \mathrm{r}$.

93 Z supliki plebana zabłudowskiego do Ludwiki Karoliny z 1685 r. wynika, że na mocy przywilejów Chodkiewiczów i Radziwiłłów pleban otrzymywać miał 200 zł jurgieltu, co potem zmniejszono do 100 zł. AGAD, AR, dz. VIII, nr 650, s. 10.

94 LMAB, f. 67, nr B-53, k. 205 v, Liber visitationis 1633.

95 B. Radziwiłł, op. cit., s. 132.

96 AGAD, AR, dz. V, t. 97, nr 4485, Albrycht Gorecki do Janusza Kiszki, z Grodna 7 luty 1653 r., w: B. Radziwiłł, op. cit., Aneksy, list nr 9, s. 212-214.

97 Archiwum Diecezjalne w Białymstoku (dalej ADB), Teczka Zabłudów: status causa. 1662-1663. 
jąc własnego kandydata, ale na to $\mathrm{z}$ kolei nie zgodził się biskup. Wieczorkowski wystosował pod adresem Radziwiłła wiele zarzutów, o dziesięcinę, której ten nie płacił, o przechowywanie arian (o czym już mówiliśmy), poza tym domagał się wsi na potrzeby parafii, a w czerwcu 1662 roku wystosował w Grodnie pozew przeciw Radziwiłłowi. Energiczne działanie plebana zabłudowskiego nie spotkało się jednak z uznaniem mieszczan zabłudowskich, którzy zapewne pod wpływem księcia (bądź jego zarządców) wystosowali suplikę do biskupa wileńskiego Jerzego Białłozora, wyliczając różne krzywdy jakich doznali od księdza Faustyna. Radziwiłł z kolei 12 lipca 1662 roku zwrócił się o poparcie do sejmiku ziemi grodzieńskiej, gdzie tłumaczył szlachcie, iż ks. Wieczorkowski jest nielegalnym proboszczem zabłudowskim, ponieważ nie dostał od niego prezenty, a jak się sprawuje wie dobrze cała okolica ${ }^{98}$. Jeszcze dwa lata trwała walka radziwiłłowskich starostów $\mathrm{z}$ energicznym plebanem. Dopiero w 1665 r. sytuacja została opanowana na drodze polubownej ugody, a na plebanii zabłudowskiej osiadł "niewichrowaty" ksiądz Gulczewski ${ }^{99}$. Ksiądz Wieczorkowski zaś wszystkie swoje pretensje umorzył i „onych de facto" się zrzekł ${ }^{100}$. Sprawa ta dała się Radziwiłłowi na tyle mocno we znaki, że od następców Wieczorkowskiego wymagał deklaracji „posłuszeństwa, skromności, przestrzegania prawa oraz tego aby nic od poddanych nie pobierali prócz dziesięciny ${ }^{101}$. Choć w pierwszej połowie XVII wieku wyznawcy różnych religii żyli obok siebie w miarę spokojnie, to po „potopie" konflikty na tle wyznaniowym były coraz częstsze, a Radziwiłłom coraz trudniej było zapanować nad sytuacją. Już w 1648 rokn doszło w Węgrowie do poturbowania tamtejszego ministra, wybitnego teologa, Macieja Apollsa Styrzyńskiego i prześladowania zboru przez księży katolickich ${ }^{102}$. Według Dyjakiewicza cała akcja sterowana była przez katolickie władze zwierzchnie ${ }^{103}$ (łuckie?). W latach siedemdziesiątych Jan

98 J. Tazbir, Arianie w Biatymstoku..., s. 97.

99 AGAD, AR, dz. V, t. 188, nr 8916, Krzysztof Łopata do Bogusława Radziwiłła, z Zabłudowa 21 marca 1666 r.

100 ADB, teczka Zabłudów, Rezygnacja Ks. F. Wieczorkowskiego z parafii zabłudowskiej, 28 maja $1664 \mathrm{r}$.

101 ADB, teczka Zabłudów, Assecuratia ks. Suszczewicza, plebana zabłudowskiego dana księciu Bogusławowi Radziwiłłowi, 3 maja 1669 r. Podobnych deklaracji posłuszeństwa wymagała też Ludwika Karolina, np. w przypadku księdza Jana Tomaszewicza prezentowanego przez nią do objęcia probostwa w Sielcu. AGAD, AR, dz. VIII, nr 498, s. 1-2, Grodno, 26 listopada $1681 \mathrm{r}$.

102 LMAB, f. 40, nr 359, k.2, Węgrów 3 czerwca 1648 r.

103 T. Wyszomirski, Zbór protestancki..., s. 140-141. 
Bonawentura Krasiński sprowadził do Węgrowa reformatów, żeby ostatecznie rozprawić się z gniazdem herezji. Zakonnicy nie przebierali w środkach, grozili klątwąi potępieniem ludziom utrzymu jącym z „heretykami” jakiekolwiek stosunki. Wreszcie w 1678 spalili zbór węgrowski ${ }^{104}$. Z trudem, wbrew władzom biskupim łuckim, zbudowano zbór zastępczy, zwykłą szopę, jak pisał Dyjakiewicz, i taka już pozostała w Węgrowie. Cóż z tego, że zbory litewskie posiadały osobowość prawną, a najście na nie traktowane winno być jak najście na dom szlachecki? Dopóki żył Radziwiłł udawało mu się, choć $\mathrm{z}$ coraz większym trudem zapewnić protestantom tarczę ochronną. Po jego śmierci zdani oni byli wyłącznie na siebie i nie mieli szans z coraz bardziej ekspansywnym, wspieranym przez króla Kościołem katolickim. Janusz Tazbir wątpi, czy książę, nawet gdyby pożył o dwadzieścia lat dłużej, byłby $\mathrm{w}$ stanie zapobiec likwidacji zborów, a to $\mathrm{z}$ racji na załamanie się już po „potopie" tolerancji w Wielkim Księstwie Litewskim ${ }^{105}, \mathrm{z}$ drugiej strony powszechnie w literaturze tłumaczy się fakt słabości kalwinizmu litewskiego w XVIII wieku brakiem patronatu ze strony choćby nawet jednej rodziny magnackiej.

\section{Prawosławni i unici}

Struktura Cerkwi prawosławnej na Podlasiu zmieniała się kilkakrotnie. Cerkwie podlaskie pozostające przy „dawnej wierze ruskiej” podporządkowane były w początkach XVII wieku jurysdykcji protopopów: bielskiego, drohickiego, brzeskiego, grodzieńskiego i zabłudowskiego. Szczególną rolę odgrywał tu namiestnik zabłudowski Nestor Kuźmicz - egzarcha metropolii kijowskiej i patriarchy konstantynopolitańskiego. Faktycznie do niego należał zarząd nad cerkwiami byłej diecezji metropolitarnej. Po 1620 roku cerkwie podlaskie podlegały jurysdykcji władyki chełmsko-bełzskiego, a po 1633 r. biskupowi łucko-ostrogskiemu ${ }^{106}$. W dobrach radziwiłłowskich znajdowało się 5 cerkwi prawosławnych: w Sokołowie, Zabłudowie i Dojlidach oraz dwie w Orli. Obecność supraskiego unickiego monasteru silnie oddziaływała na cerkwie prawosławne na Podlasiu. Większość z nich też sukcesywnie

104 Ibidem, s. 147. J. Maroszek, Klasztory Podlasia, źródta kultury i świadomości narodowej, Białystok 1995, s. 57.

105 J. Tazbir, Reformacja w Polsce..., s. 127.

106 A. Mironowicz, Podlaskie ośrodki i organizacje prawostawne w XVI i XVII wieku, Białystok 1991, s. 175-176. 
przyjmowała unię. Nie dotyczyło to, jak się wydaje, cerkwi znajdujących się w dobrach radziwiłłowskich, choć zakonnicy suprascy domagali się od Krzysztofa Radziwiłła podporządkowania im cerkwi zabłudowskiej. Radziwiłłowie zachowali uprawnienia kolatorskie w stosunku do Cerkwi prawosławnej w swoich dobrach. Podobnie jak w przypadku Kościoła katolickiego, zachowali prawo do preznety duchownych prawosławnych na stanowiska, uposażania finansowego parafii i duchownych, wyrażania zgody na remonty cerkwi. Już w 1596 roku Krzysztof „Piorun” uposażył popa orlańskiego Pendrzejewicza i dał mu przywilej na dom ${ }^{107}$. Mimo decyzji synodu z 1615 roku zabraniającego budowania i dobudowywania cerkwi w majętnościach szlacheckich konfesji ewangelickiej ${ }^{108}$, Radziwiłłowie w swoich dobrach podlaskich cerkwi, co prawda, nie budowali, ale dość często je uposażali. Janusz Radziwiłł, wojewoda wileński, potwierdzając w 1643 roku przywilej miejski dla Orli, zezwolił duchownemu oraz bakałarzowi istniejącej przy cerkwi szkółki na łowienie ryb oraz wyrąb lasów we włości. Zwolnił również budynki parafialne od opłat i podatków. Dziesięć lat później nadał o. Piotrowi Łoźnickiemu przywilej na tzw. popowszczyznę, czyli plac zwolniony z opodatkowania ${ }^{109}$. W 1694 roku Ludwika Karolina zastawiła dobra orlańskie na trzy lata katolikowi Benedyktowi Pawłowi Sapieże, podskarbiemu wielkiemu litewskiemu, a w akcie zastawnym uczyniła zapis, iż „ius patronum do cerkwi orleńskiej mnie samej i sukcesorom moim rezerwuję i wyjmuję" ${ }^{110 . ~ S ́ w i a d c z y ~}$ to o tym, że w końcu XVII, wbrew temu co wynikałoby z literatury przedmiotu, w Orli zachowała się jednak cerkiew prawosławna. Gdyby bowiem przeszła ona na unię, dokument zastawny nie wyłączałby cerkwi prawosławnej. W 1661 roku Bogusław Radziwiłł, na prośbę popa Zaleskiego z cerkwi sokołowskiej, polecił Janowi Niewiarowskiemu przekazać jedną włókę na jej potrzeby ${ }^{111}$. W roku 1659 Maria Radziwiłłowa, gorliwa wyznawczyni prawosławia, mocą swojego testamentu uposażyła monaster reguły św. Bazylego i 12 zakonników w Zabłudowie przy cerkwi Zaśnięcia NMP oraz kolegium dla „dziatek ruskich i łacińskich” ${ }^{112}$. O testament i zapisy po Radziwiłło-

107 LMAB, f. 40, nr 462, s. 15, AGAD, AR, dz. VIII, nr 435, s. 1, Orla 2 sierpnia $1596 \mathrm{r}$.

108 LMAB, f. 40, nr 1157, k. 41, 1615 r.

109 NHAB, f. 694, op. 4, nr 1466, k. 281-282.

110 NHAB, f. 694, op. 4, nr 1035, k. 19, cyt. za G. Sosna, D. Fionik, Orla na Podlasiu. Dzieje cerkwi, miasta i okolic, Bielsk Podlaski, Rybołty, Białystok 1997, s. 35.

111 AGAD, AR, dz. IV (kopie), t. 1, nr 7, k. 540.

112 AGAD, AR, dz. VIII, nr 654, s. 5-8, druk: Prawa i przywileje dóbr ziemskich i miasta Zabłudów..., s. 195-199. 
wej wybuchł długi spór sądowy ciągnący się aż do XIX wieku ${ }^{113}$. Pretensje zgłaszali nie tylko prawosławni, ale też unici z Gabrielem Kolendą, ks. bazylianinem, arcybiskupem połockim na czele ${ }^{114}$. W 1666 roku Kolenda obłożył księcia ekskomuniką i nakazał przekazanie cerkwi unitom. Także sąd ziemski grodzieński nakazał Radziwiłłowi zwrot cerkwi i wypłacenie unitom zaległej dziesięciny. Książę cerkwi nie oddał i pozostała ona w rękach prawosławnych, natomiast Gabriel Kolenda zrzekł się pretensji do zapisu po Marii Wołoszce dotyczących cerkwi zabłudowskiej ${ }^{115}$. Antoni Mironowicz uważa, że fundacja monasteru miała miejsce przed 1655 rokiem, a dokonał jej Janusz Radziwiłł ${ }^{116}$. Z kolei z ustaleń Józefa Maroszka wynika, że nie ma podstaw do twierdzenia, iż powstał on przed 1655 rokiem, a jego utworzenie związane jest $\mathrm{z}$ testamentem Marii Radziwiłłowej ${ }^{117}$. W 1695 roku zakonnicy $\mathrm{z}$ tegoż monasteru skarżyli się Ludwice Karolinie, że od piętnastu lat nie otrzymują dziesięciny, które wg funduszów fundatorów winni otrzymywać ${ }^{118}$.

\section{$\dot{Z} \mathbf{y d z i}$}

Żydzi Podlasia w XVI wieku wraz z największą gminą w Tykocinie wchodzili w skład ziemstwa litewskiego i pozostali w tym ziemstwie po 1569 r. W 1629 roku Żydzi Podlasia odłączyli się i przystąpili do sejmu Żydów Korony, w którym pozostali jako okręg podlaski do drugiej połowy XVII wieku, kiedy to $\mathrm{z}$ kolei powstały w województwie podlaskim dwa okręgi: węgrowski i tykociński. Wyznawcy wyznania mojżeszowego w dobrach radziwiłłowskich zorganizowani byli w cztery gminy: w Orli (od 1616 r. gmina), Węgrowie (od 1595 r. gmina), Sokołowie i Zabłudowie ${ }^{119}$. W podlaskich mia-

113 T. Wasilewski, Walka o spadek po księznej Marii Wołoszce, wdowie po Januszu Radziwille, w latach 1660-1690, "Miscellanea Historico-Archivistica”, t. III, s. 291-308.

114 AGAD, AR, dz. VIII, nr 653, s. 2, druk: Prawa i przywileje miasta i dóbr ziemskich Zabtudów..., dok. 33, s. 220-221, 1665 r.

115 Prawa i przywileje miasta i dóbr ziemskich Zabłudów..., dok. 37, s. 228-229, Wilno 10 marca $1671 \mathrm{r}$.

116 A. Mironowicz, Kościót prawostawny w dziejach dawnej Rzeczypospolitej, Białystok 2001, s. $117,215$.

117 J. Maroszek, Klasztory Podlasia, źródła kultury i świadomości narodowej, Białystok, s. 60-61; Prawa i przywileje miasta i dóbr ziemskich Zabłudów..., s. 199.

118 Prawa $i$ przywileje miasta $i$ dóbr ziemskich Zabtudów..., dok. 57, s. 272-273, 25 marca 1695 r.

119 A. Leszczyński, Z dziejów Żydów Podlasia (1487-1795), „Studia Podlaskie” 1989, t. II, s. 22 . 
stach radziwiłłowskich pojawili się oni już w XVI wieku, najwcześniej chyba w Węgrowie, bo wzmianki o ich obecności sięgają 1537 roku. Podstawą prawną do zorganizowania gminy (kahału) była zgoda (przywilej) właściciela miasta. W 1618 r. Krzysztof II Radziwiłł zezwolił ludziom wszelkiego stanu w Orli, w tym Żydom, fundować się i budować120, w 1638 r. zezwolił Żydom zabłudowskim na budowę bożnicy ${ }^{121}$, a Janusz Radziwiłł w 1645 r. nadał im rozległe prawa ${ }^{122}$. Kolejne przywileje otrzymywali Żydzi zabłudowscy od Bogusława Radziwiłła ${ }^{123}$ i Ludwiki Karoliny. Mieli oni prawo do budowy karczm, kramów i szynków ${ }^{124}$. Te ostatnie wzbudzały najwięcej zastrzeżeń wśród miejscowej ludności chrześcijańskiej skarżącej się, że Żydzi pozbawiają ich dochodów i że handlują nieuczciwie ${ }^{125}$. Również pleban zabłudowski w wystosowanej do Ludwiki Karoliny suplice żądał, „aby Żydzi w niedzielę gorzałek nie palili, targów nie odprawiali, kramów nie odmykali". Z zapisków sporządzonych na marginesie supliki wynika, że Radziwiłłówna podzielała jego zarzuty ${ }^{126}$. Przy kahałach istniały również szkoły żydowskie. W 1679 roku kupcy żydowscy posiadali w Zabłudowie 16 kramów. Ciekawe jest, że księża katoliccy często korzystali z usług kahału i tam składali sumy pochodzące $z$ legacji.

\section{Zakończenie}

Oceniając politykę wyznaniową Radziwiłłów w ich dobrach podlaskich, stwierdzić trzeba, że była ona bardzo liberalna w stosunku do ludzi różnych wyznań. W końcu XVI wieku zastali oni społeczeństwo bardzo zróżnicowane religijnie i nie starali się wnosić istotnych zmian do tego stanu. Ocena ludzi nie przebiegała po linii wyznaniowej, ale zawahałabym się też przed stwierdzeniem, że podział ten przebiegał wyłącznie po linii użyteczności politycznej bądź ekonomicznej. Sami, choć kalwiniści, to przecież nie fanatyczni,

120 APB, Kamera Wojny i Domen, nr 2899, k. 45.

121 Prawa i przywileje miasta $i$ dóbr ziemskich Zabtudów..., dok. 18, s. 180, Świadość 3 kwietnia $1638 \mathrm{r}$.

122 Ibidem, dok. 21, s. 187-190, Zabłudów 23 kwietnia 1645 r.

123 Ibidem, dok. 28-30, s. 206-211, Zabłudów 10 lutego 1662 r.

124 lbidem, dok. 41, 45, 46, s. 236-237, 244-247.

125 Ibidem, dok. 49, s. 252-253, 19 lipca 1686 r.

126 AGAD, AR, dz. VIII. Nr 650, s. 8, Memoriał księdza plebana zabłudowskiego do Ludwiki Karoliny, 22 czerwca 1685 r. 
i choć ochraniali i propagowali ewangelików tạm mieszkających, nie starali się swojego wyznania narzucić innym siłą. Zrównanie w prawach wszystkich mieszkańców łącznie ze Szkotami czy Żydami, w ich podlaskich miasteczkach, (na tyle, na ile było to możliwe) należy ocenić w sposób pozytywny, zdając sobie jednocześnie sprawę $z$ tego, że motywem decydu jącym takiego postępowania były względy ekonomiczne. Co prawda, najbliżsi ich współpracownicy na Podlasiu to ewangelicy lub arianie (zwłaszcza w pierwszej połowie XVII wieku) wywodzący się spoza tego regionu, to przecież szlachta podlaska w swej masie zdecydowanie katolicka pełniła u nich odpowiedzialne funkcje gospodarcze i polityczne; byli urzędnikami, starostami, zarządcami dóbr, ale także konfidentami politycznymi czy dzierżawcami dóbr. Wśród tych ostatnich byli też miejscowi Żydzi, od których tė̇ często pożyczali pieniądze. Znajdujemy również szlachtę podlaską w wojskach radziwiłłowskich ${ }^{127}$. Oczywiście trzeba sobie zadać pytanie o to, czy w dobie postępującej nietolerancji religijnej i kontrreformacji wspieranej przez dwór królewski, mogli sobie w XVII wieku pozwolić na narzucanie komukolwiek własnego wyznania. Z pewnością - nie. Nie spotykamy się tam jednak z sytuacją, w której dyskryminowano by kogoś za wiarę. Pewien wyjątek to arianie, przy czym stosunek Radziwiłłów do tej grupy wyznaniowej już dawno został uznany przez historyków za wybitnie niekonsekwentny. Procesy sądowe z księżmi katolickimi nie oznaczały przecież walki z miejscową społecznością katolicką, a antyklerykalizm, jak wynika to choćby z ostatniego artykułu Janusza Tazbira, miał w Rzeczypospolitej długą tradycję ${ }^{128}$.

127 P. Rudnicki, Drobna szlachta podlaska w wojskach radziwitłowskich $w$ XVII wieku, w: Drobna szlachta podlaska w XVI-XVII wieku, pod red. S. K. Kuczyńskiego, Białystok 1991, s. 39-56.

128 J. Tazbir, Antyklerykalizm staropolski, „KH” 2002, t. CIX, z. 3, s. 13. 